\title{
Circulating tumor cells in prostate cancer: Precision diagnosis and therapy (Review)
}

\author{
WEIWEI LIU, BINBIN YIN, XUCHU WANG, PAN YU, XIUZHI DUAN, \\ CHUNHUA LIU, BEN WANG and ZHIHUA TAO
}

\begin{abstract}
Department of Laboratory Medicine, The Second Affiliated Hospital of Zhejiang University School of Medicine, Hangzhou, Zhejiang 310009, P.R. China
\end{abstract}

Received January 30, 2016; Accepted March 9, 2017

DOI: $10.3892 / \mathrm{ol} .2017 .6332$

\begin{abstract}
The primary cause of tumor-associated mortality in prostate cancer $(\mathrm{PCa})$ remains distant metastasis. The dissemination of tumor cells from the primary tumor to distant sites through the bloodstream cannot be detected early by standard imaging methods. Circulating tumor cells (CTCs) represent an effective prognostic and predictive biomarker, which are able to monitor efficacy of adjuvant therapies, detect early development of metastases, and finally, assess therapeutic responses of advanced disease earlier than traditional diagnostic methods. In addition, since repeated tissue biopsies are invasive, costly and not always feasible, the assessment of tumor characteristics on CTCs, by a peripheral blood sample as a liquid biopsy, represents an attractive opportunity. The implementation of molecular and genomic characterization of CTCs may contribute to improve the treatment selection and thus, to move toward more precise diagnosis and therapy in $\mathrm{PCa}$. The present study summarizes the current advances in CTC enrichment and detection strategies and reviews how CTCs may contribute to significant insights in the metastatic process, as well as how they may be utilized in clinical application in
\end{abstract}

Correspondence to: Professor Zhihua Tao, Department of Laboratory Medicine, The Second Affiliated Hospital of Zhejiang University School of Medicine, 88 Jiefang Road, Hangzhou, Zhejiang 310009, P.R. China

E-mail: zrtzh@zju.edu.cn

Abbreviations: AA, abiraterone acetate; AR, androgen receptor; AR-V7, androgen receptor splice variant 7; CRPC, castration-resistant prostate cancer; CTC, circulating tumor cell; EMT, epithelial-mesenchymal transition; EpCAM, epithelial cell adhesion molecule; mCRPC, metastatic castration-resistant prostate cancer; OS, overall survival; $\mathrm{PCa}$, prostate cancer; PCA3, prostate cancer antigen 3; PCTC, prostate cancer circulating tumor cell; PSA, prostate-specific antigen; PSMA, prostate specific membrane antigen; TMPRSS2-ERG, transmembrane protease serine 2 and ETS-related fusion gene

Key words: prostate cancer, circulating tumor cell, liquid biopsy, epithelial-mesenchymal transition, metastasis, prognostic, predictive
PCa. Although it is proposed that CTCs may offer insights into the prognosis and management of $\mathrm{PCa}$, there are a number of challenges in the study of circulating tumor cells, and their clinical utility remains under investigation.

\section{Contents}

1. Introduction

2. Enrichment and detection strategies for CTC

3. Clinical application of CTCs in $\mathrm{PCa}$

4. CTC culture

5. Conclusion

\section{Introduction}

Prostate cancer (PCa) is the most common urological malignancy and the second leading cause of male cancer-associated mortality in numerous developed countries (1). The rate of diagnosis differs between countries due to the difference in coverage of prostate-specific antigen (PSA) screening (2), but in populations with and without PSA screening, $\mathrm{PCa}$ is the cause of $1-2 \%$ of all mortality for men (3). Its greater prevalence in the West implicates lifestyle and environmental risk factors (4). Significant progress has been made in the treatment and understanding of the underlying biology (5-7). This includes the approval of several novel effective drugs that prolong life in men with advanced $\mathrm{PCa}$, and the recognition that the terms hormone refractory and androgen-independent were misnomers. The majority of cancers remain hormone-driven despite castration resistance (8-13). Although the improvements in PCa detection and multiple treatments have led to a significant decrease in PCa-associated mortalities in the last three decades, the majority of men initially diagnosed with early-stage cancer eventually develop metastatic disease (14). Thus, PCa currently remains challenging to treat, and the aims of therapy are the improvement of overall survival (OS) time and quality of life.

Multiple clinical and pathological features, such as bone scan assay and quantitative imaging parameters (15), and laboratory biochemical indicators, such as PSA (16), currently guide treatment decision making in PCa. However, the lack of reliable prognostic and predictive factors and imperfect tools 
to precisely diagnose and evaluate treatment success in the primary and metastatic setting continues to result in serious overtreatment and invalid treatment of patients (17). Novel strategies to improve diagnosis, earlier indications of treatment response and treatment failure, and improved definition of patient cohorts that will respond to a specific treatment in primary and metastatic PCa are therefore urgently required.

Circulating tumor cells (CTCs) are cancer cells that are present in the blood of patients with solid cancers and are shed from existing tumor lesions into the bloodstream (18). Numerous laboratory studies and clinical trials in the past two decades have shown that CTCs may be used as a biomarker to predict disease progression and survival in patients with metastatic, advanced (19-22) or even early-stage PCa (23). High CTC numbers are associated with aggressive disease, increased metastasis and decreased time to relapse $(22,24,25)$. In addition, CTCs isolated from patients with metastatic $\mathrm{PCa}$ (mPCa) may initiate metastasis in a xenograft model (26). A growing number of studies have shown that CTCs are a source of metastatic cells (27-29); CTCs have become an integral part of tumor staging criteria, which are currently focused on several types of tumors, including breast cancer (30), PCa (29), lung cancer (31) and colorectal cancer (32). Since blood collection is simple, convenient and minimally invasive, CTCs may be used as a real-time liquid biopsy for disease progression and survival (19). CTCs also have potential to guide therapeutic management (33), indicate tumor sensitivity to therapy, monitor therapy effectiveness or necessity, even in the absence of detectable metastases (33), offer insights into mechanisms of drug resistance (34) and promote new anti-drug research and development to a certain degree (35). CTCs may also be utilized as a surrogate endpoint marker in clinical trials (36), and may also become a promising tumor target. Despite the potential, the use of CTCs faces numerous challenges.

This review describes the current state of research into CTCs enrichment and detection strategies and clinical application, the evidence to demonstrate their diagnostic validity and therapeutic value, and their potential impact for future clinical trial design and therapeutic decision-making processes in $\mathrm{PCa}$.

\section{Enrichment and detection strategies for CTC}

PCa circulating tumor cells (PCTCs) are present in the bloodstream at a low concentration, ranging between 1-10 cells per $10 \mathrm{ml}$ in the majority of patients with cancer, which poses a serious challenge for any analytical system (18). The problem exists of looking for the proverbial 'needle in the haystack'. Thus, the detection and characterization of PCTCs requires highly sensitive and specific techniques, which consist of a combination of enrichment (isolation) and detection (identification) strategies, and these two steps are essential components of the identification process (23). It was not until recently that such sensitive molecular techniques were developed.

CTC enrichment approaches. CTCs can be isolated from blood cells based on cell size (37), density and positive immunoselection, such as epithelial cell adhesion molecule (EpCAM) (38) and prostate-specific membrane antigen (PSMA) (39) antibody-based enrichment of CTCs, or negative immunoselection, such as depletion of leukocytes by CD45 $(40,41)$ antibody. Current CTC enrichment approaches are summarized in Table I.

Several membrane filter devices are available for CTC enrichment based on the differential cellular size, including isolation by size of epithelial tumor cells, micro electro-mechanical system-optics based microfilter, ScreenCell ${ }^{\circledR}$, CellSieve $^{\mathrm{TM}}$ and CellOptics ${ }^{\circledR}$ (42). Recently, Qin et al (43) used the resettable cell trap mechanism to separate cells based on their size and deformability using an adjustable aperture that can be periodically cleared to prevent clogging. This system was able to capture $\geq 5$ CTCs in $18 / 22(82 \%)$ patients with a mean count of 257 in $7.5 \mathrm{ml}$ of whole blood, while the CellSearch system found $\geq 5$ CTCs in 9/22 (41\%) metastatic castration-resistant PCa (mCRPC) with a mean count of 25 in the $7.5 \mathrm{ml}$ whole blood samples. Filtration by size consents to enrich CTCs from a wide range of tumors, but occasionally results in loss of smaller CTCs or clotting of filter pores by leukocytes (40). In addition, emerging CTC capture strategies typically distinguish these cells based on cultured cancer cells. However, CTCs were found to have significantly smaller size, larger nuclear-cytoplasmic ratio and more elongated shape (44), which may inevitably degrade the performance of the cell size-dependent capture system. Another morphology-based enrichment strategy is based on density gradient centrifugation using Ficoll-hypaque solution (45). Ficoll density gradient-dependent techniques are easy to operate, even if real losses of tumor cells have been observed (46).

Immunoselection is the most commonly used approach for CTC enrichment, which relies on specific CTC markers that are detected by antibodies (39). Epithelial markers are expressed on epithelial tumors, but not on blood cells, and have therefore been used to isolate CTCs from blood cells (47). EpCAM and members of the family of cytokeratin (CK)s (CK8, CK18 and CK19) have been markers for positive selection in $\mathrm{PCa}$ (47). Thus far, the most successful approach belongs to the CellSearch ${ }^{\circledR}$ System (Veridex LLC, Raritan, NJ, USA), which employs ferromagnetic nanoparticles coupled to EpCAM antibodies for CTC capture, became the first validated CTC assay approved by the Food and Drug Administration (FDA) in $2008(48,49)$. With this system, CTCs are isolated using ferrofluid covalently linked to an antibody against the surface of EpCAM (48). CTCs are differentiated from leukocytes by labeling the product with monoclonal antibodies against CKs (CTC markers) and CD45 (leukocyte marker) $(38,48,49)$. The labeled sample is analyzed by an automated fluorescence detection system (CellTracks ${ }^{\circledR}$ Analyzer; Veridex LLC) $(48,49)$. However, the limitation of the CellSearch System is that EpCAM-negative tumor cells may not be detected. Downregulation of EpCAM may occur during the epithelial-mesenchymal transition (EMT), a process linked to tumor cell invasion and dissemination, and to the stemness of cancer cells (50). Mesenchymal-based capture is a strategy that isolates cells based on osteoblast (OB)-cadherin cell surface expression (51). Using this method, OB-cadherin cellular events are detectable in men with $\mathrm{mPCa}$ and are less common in healthy volunteers. This method may complement existing epithelial-based methods and may be particularly useful in patients with bone metastases (51). For PCa, PSMA presents a compelling target for immunocapture, as PSMA levels increase in higher-grade cancers and metastatic disease 
Table I. Advantages and disadvantages of CTC enrichment approach.

\begin{tabular}{|c|c|}
\hline Technology and rationale & Advantages \\
\hline Isolation by size & $\begin{array}{l}\text { Easy and rapid; enrichment of } \\
\text { CTCs from a wide range of tumors; } \\
\text { feasible for EpCAM-negative CTCs }\end{array}$ \\
\hline Density gradient centrifugation & $\begin{array}{l}\text { Operability; feasible for } \\
\text { EpCAM-negative CTCs }\end{array}$ \\
\hline Immunoselection & $\begin{array}{l}\text { Visual confirmation of CTCs } \\
\text { and quantitative }\end{array}$ \\
\hline
\end{tabular}

Microfluidics device
Dependent or independent of tumor membrane epitopes; high recovery and efficiency; potential to recover CTCs for additional characterization
Disadvantages

(Refs.)

Loss of smaller CTCs or

clotting of filter pores

by leukocytes

Loss of some CTCs

Costly and absence

of standardized methods

and reagents

High technical requirement;

absence of standardized

methods; early in

development

CTCs, circulating tumor cells; EpCAM, epithelial cell adhesion molecule.

and are specific to the prostate epithelium (39). In order to overcome this drawback, PSMA-based positive immunoselection was developed and may successfully capture the EMT CTCs (39). Santana et al (52) used monoclonal J591 antibodies and $\mathrm{J} 415$-antibodies that are highly specific for intact extracellular domains of PSMA on live cells in microfluidic devices for the capture of LNCaPs. The results showed that J591 outperforms J415 and a mix of the two for PCa capture, and that capture performance saturates following incubation with antibody concentrations of $10 \mu \mathrm{g} / \mathrm{ml}$. In addition, negative selection for the antigens CD45 (expressed in leukocytes) and CD61 (expressed in megakaryocytes and platelets) may markedly reduce and avoid contamination by blood cells (53). The major advantage of immune-based separation is that CTCs can be directly visualized and quantified without requiring cell lysis. Its limitations include cost and variability, due to the absence of standardized methods and reagents (53).

Several other devices based on physical and/or biological properties of CTCs are available, including a NanoVelcro Chip assay (54), aptamer-conjugated graphene oxide membranes (55) and a microfluidics device that combines the multi-orifice flow fractionation and the dielectrophoresis/acoustophoresis cell separation techniques $(56,57)$, among which the microfluidics device holds promise for CTC enrichment. Ozkumur et al (58) described an inertial focusing-enhanced microfluidic CTC capture platform, termed CTC-iChip, which is capable of sorting rare CTCs from whole blood at $10^{7}$ cells/sec. Most importantly, the iChip is capable of isolating CTCs using strategies that are either dependent or independent of tumor membrane epitopes, and thus applicable to virtually all cancers. A technology that uses magnetic particles bearing tumor cell-specific EpCAM antibodies, self-assembled in a regular array in a microfluidic flow cell was reported recently (59), which could capture CTCs in $75 \%$ of patients with $\mathrm{mPCa}$ and $80 \%$ of patients with metastatic breast cancer, and showed similar or improved results compared with the CellSearch device in 10 out of 13 samples. In addition, a single inlet two-stage acoustophoresis chip could enrich PCa cells from white blood cells, DU145 spiked into blood were enriched from white blood cells at a sample flow rate of $100 \mu \mathrm{l}$ min (-1), providing $86.5 \pm 6.7 \%$ recovery of the cancer cells with $1.1 \pm 0.2 \%$ contamination of white blood cells, and by increasing the acoustic intensity a recovery of $94.8 \pm 2.8 \%$ of cancer cells was achieved with $2.2 \pm 0.6 \%$ contamination of white blood cells (60). Notably, Sarioglu et al (61) developed a microchip technology (the Cluster-Chip) to capture CTC clusters independently of tumor-specific markers from unprocessed blood. CTC clusters are isolated through specialized bifurcating traps under low-shear stress conditions that preserve their integrity, and even two-cell clusters are captured efficiently (61).

CTC detection approaches. Following enrichment, CTCs require subsequent identification at the single-cell level and to be separated from normal blood cells. Detection of CTCs may be performed through immunology-based techniques or nucleic acid-based techniques.

Immunology-based techniques. Immunology-based techniques are the most common of the strategies and are effective for detection and isolation of CTCs. Immunological methods utilize labeled antibodies directed against epithelial or tumor-associated antigens, along with automated digital microscopy or flow cytometry, to identify and quantify CTCs (42). Numerous antigens have been used for this method, including EpCAM and different subtypes of CKs (62). However, not all CTCs express these markers, possibly as a consequence of the EMT process, and likely lead to false-negative results (62). In addition, tumor-specific antigens are expressed at an increased level in cancer cells compared with normal cells. PSA and PSMA are PCa-associated markers for detecting CTCs, and have been applied in antibody-based detection and isolation of CTCs (63-65).

EpCAM-based immunological assays are the most common of the strategies for CTC detection. Among the recently developed innovative techniques, the CellSearch ${ }^{\circledR}$ system is the most advanced commercially available technology with combined automated enrichment and immunostaining (48). 
Currently, it is the only technology that has been approved by the USA FDA for the detection of patients with mPCa (22). The CD45 marker is employed to rule out white blood cells and increase detection specificity (66). A CTC is often defined as a $\mathrm{CK}^{+} / \mathrm{CD}^{2} / / \mathrm{DAPI}^{+}$intact cell (66). The nuclear dye DAPI is used to exclude cell fragments and debris false-positive may occur using CK as a marker (66). Notably, this technique allows quantitative measurement of CTCs and it may provide a more precise discrimination between patients (62).

In addition to the CellSearch ${ }^{\circledast}$ system, a variety of novel detection technologies have been developed. Myung et al (67) engineered a novel multifunctional surface, on the basis of the biomimetic cell capture, through optimized incorporation of multiple antibodies directed to cancer cell-specific surface markers, including EpCAM, human epidermal growth factor receptor-2 and PSA, which may lead to clinically significant, differential detection of CTCs that are rare and highly heterogeneous.

Nucleic acid-based techniques. Nucleic acid-based techniques have become the most widely used alternative to immunology-based techniques, which are considered to be more sensitive than protein-based approaches (68). Particularly, polymerase chain reaction (PCR)-based assays evaluate the amount of DNA from CTCs. However, the drawback of this technique is the inability to distinguish the DNA free in the blood from apoptotic cells, creating false-positive results (68). Therefore, the majority of research groups prefer reverse transcription (RT)-PCR assays to detect specific mRNA, since only viable CTCs produce mRNA (69-71). Several specific mRNA markers are used to identify PCTCs in nucleic acid-based methods (Table II).

To date, the mRNA encoding PSA has been the most extensively studied in clinical trials $(63,69,72)$. Mohamadi et al (73) developed a velocity valley chip to efficiently capture magnetic nanoparticle-bound CTCs. The approach was successfully validated using samples collected from patients with PCa: CTCs and PSA mRNA sequences were detected in all cancer patient samples and not in the healthy controls. In addition, quantitative RT-PCR analysis of PSA and PSMA mRNA to detect circulating tumor cells improves recurrence-free survival nomogram prediction following radical prostatectomy (72). Furthermore, androgen receptor (AR), kallikrein-related peptidase (KLK)2, KLK3, PCa antigen 3 (PCA3), transmembrane protease serine 2 and ETS-related fusion gene (TMPRSS2-ERG), AR splice variant 7 messenger RNA (AR-V7) and prostate stem cell antigen mRNA are also utilized to identify PCTCs $(63,69,74-76)$. However, the major limitations to these techniques are associated with the mRNA markers utilized, since they may be also present at low concentrations in normal blood, bone marrow cells and in other non-tumor cells (77). Therefore, to seek more specific mRNA markers is the key issue in future studies.

In addition to the aforementioned types of commonly used CTC detection techniques, certain novel technologies are also in rapid development, particularly sensor-based detection technologies, which show high sensitivity and specificity (78). Sioss et al (78) selected PCA3 RNA as a marker and developed a nanoresonator chip-based sensor for detection of prostate circulating tumor cells. Similarly, Ivanov et al (79) described
Table II. Specific mRNA markers for detection of prostate cancer circulating tumor cells.

\begin{tabular}{lc} 
mRNA markers & (Refs.) \\
\hline PSA & $(72,73)$ \\
PSMA & $(72)$ \\
PCA3 & $(75)$ \\
PSCA & $(69)$ \\
AR & $(74)$ \\
AR-V7 & $(76)$ \\
TMPRSS2-ERG & $(63,75)$ \\
KLK2 & $(69)$ \\
KLK3 & $(69,75)$ \\
\hline
\end{tabular}

PSA, prostate-specific antigen; PSMA, prostate-specific membrane antigen; PCA3, prostate cancer antigen 3; AR, androgen receptor; AR-V7, androgen receptor splice variant 7; TMPRSS2-ERG, transmembrane protease serine 2 and ETS-related fusion gene; KLK, kallikrein-related peptidase.

a chip-based method using nanostructured microelectrodes and electrochemical readout, which confirmed the identity of isolated CTCs and successfully interrogated them for specific biomarkers. Recently, a light addressable potentiometric sensor was exploited in the label-free detection of CTCs in $\mathrm{PCa}$, which may be a potential platform for CTC detection and may provide a powerful tool for downstream analysis (80).

Overall, in the last two decades, several promising CTC enrichment and detection methods have been developed. These strategies should be validated in appropriately sized clinical trials in order to evaluate their quality, validity and clinical practicability.

\section{Clinical application of CTCs in PCa}

CTCs have an important role in the progression and metastasis of $\mathrm{PCa}$, and represent tumor characteristics of individual patients well. Therefore, CTCs may be used as an ideal biomarker for prognosis, prediction and clinical management of patients with PCa.

Prognostic and predictive biomarker. Utilizing multiple blood tests, CTC enumeration and characterization may provide prognostic and predictive value on $\mathrm{PCa}$, particularly in metastatic and advanced PCa (47,81-83). As early as 2005, Moreno et al (84) demonstrated that in patients with metastatic PCa, CTC enumeration with the cut-off of 5 CTCs was a predictive factor superior to other clinical variables. They also demonstrated that increased CTC numbers have been found in patients with bone metastasis compared with patients with visceral spread, which suggests a prognostic potential for CTC detecting in monitoring patients for bone disease in $\mathrm{PCa}(20-22)$. Furthermore, in patients with CRPC, post-treatment CTC counts were a stronger prognostic factor for survival than a 50\% decline in PSA [receiver operating characteristic (ROC) AUC 0.87 vs. 0.62] $(19,85)$. Therefore, for patients with CRPC with no metastases and slow-rising PSA, CTC detection 
would be complementary to PSA testing, which may be useful in facilitating decisions about additional imaging requirements and for early diagnosis of bone metastases, allowing for earlier intervention with treatments. In addition, CTC counts appear to be an earlier and more sensitive predictor for survival and treatment response compared with current objective response criteria (OR) in patients with $\mathrm{mCRPC}(86)$. Recently, Marín-Aguilera et al (87) analyzed the molecular profiling of peripheral blood from 43 patients with mCRPC with known CTC content in order to identify genes that may be associated with PCa progression. The analysis revealed a two-gene model (selenium binding protein 1 and matrix metalloprotein 9) with a high significant prognostic ability [hazard ratio (HR), 6; 95\% confidence interval $(\mathrm{CI}), 2.61-13.79 ; \mathrm{P}<0.0001]$. Notably, a phase III SWOG-led therapeutic trial demonstrated that increased CTC telomerase activity was associated with HR, $1.14(\mathrm{P}=0.001)$ for $\mathrm{OS}$ in patients with baseline CTC count $\geq 5$ (47\% of patients), subsequent to adjusting for other clinical covariates, including CTC counts and serum PSA at study entry (88).

However, CTCs were identified in $21 \%$ of patients with PCa prior to radical prostatectomy, which was similar to the rate of CTC detection in control (non-cancer) patients (89). Consistently, Loh et al (90) collected samples of peripheral blood $(7.5 \mathrm{ml})$ drawn from 36 men with newly diagnosed high-risk non-metastatic PCa, prior to any initiation of therapy, and analyzed for CTCs using the CellSearch ${ }^{\circledR}$ method. They demonstrated that patients with high-risk, non-metastatic PCa present infrequently with a small number of CTCs in peripheral blood. Furthermore, in these patients with localized PCa, CTC numbers were not associated with tumor volume, pathological stage and Gleason score, indicating that CTCs are more likely to originate from metastasis sites instead of primary lesions $(91,92)$.

Notably, a number of men have low CTCs despite widespread disease, indicating heterogeneity in CTC phenotype or detection $(93,94)$. Chen et al $(95)$ suggested that an incremental expression of EMT-associated genes in CTCs is associated with $\mathrm{mCRPC}$. It was found that genes that promote mesenchymal transitioning into a more malignant state, including insulin-like growth factor (IGF)1, IGF2, epidermal growth factor receptor, forkhead box $\mathrm{p} 3$ and transforming growth factor $\beta 3$, were commonly observed in these cells. In addition, Osmulski et al (96) found that CTCs from patients with CRPC are three times softer, three times more deformable and seven times more adhesive than counterparts from patients with castration-sensitive PCa. The present study indicates that nanomechanical phenotypes of CTCs may serve as novel and effective biomarkers for mCRPC. More recently, the detection of small nuclear CTCs was found to be associated with the presence of visceral metastases and should be formally explored as a putative blood-borne biomarker to identify patients at risk of developing this clinical evolution of PCa (24).

Overall, enumeration and characterization of CTCs has shown a strong potential in the prognosis and prediction of patients with metastatic and advanced PCa, whereas CTC detection is unreliable in the early and localized disease state.

Response-indicator and efficacy-response biomarker. An increasing number of systemic therapies with life extending capacity have become available in mCRPC, including abiraterone acetate (AA), enzalutamide, sipuleucel-T, docetaxel, cabazitaxel and radium-223 (97). More compounds are currently being evaluated in promising pivotal trials, such as Tasquinimod, ARN-509 and ODM-201 (97). Limitations of the currently available biomarkers make treatment decisions challenging (97). Considering the increasing complexity of treatment algorithms in mCRPC, the current demand of research is to identify and characterize biomarkers with prognostic, predictive and surrogate quality, allowing for information on clinically meaningful outcomes and on which therapy to offer patients in different and complex scenarios. Currently, the selection of a targeted therapy for an individual patient is based on analysis of the primary tumor for the expression and/or genomic status of a specific molecular target $(98,99)$. However, primary carcinomas, in particular $\mathrm{PCa}$, show a marked intrapatient heterogeneity in regard to genotypic and phenotypic characteristics, and tumor cells may transform dynamically during the extended time period between primary tumor resection and metastatic relapse due to parallel progression and/or natural selection of the fittest clones (100). Metastases from different sites are genetically heterogeneous (29), and CTCs have the advantage that they may represent the entire spectrum of distant metastases (101). Thus, CTC detection and characterization may become a valuable tool to refine prognosis and serve as a real-time biopsy, and has the potential to monitor cancer treatment, provide useful predictive information for the selection of the most appropriate treatment and guide precision cancer therapies (100).

A growing number of studies have demonstrated that the dynamic change of CTC count is associated with a significant curative effect $(102,103)$. Patients with CRPC received AA $1,000 \mathrm{mg}$ daily and continuously, a post-therapy CTC count of $<5$ per $7.5 \mathrm{ml}$ was prognostic for longer survival relative to a CTC count of $\geq 5$, which indicated that lower CTC enumeration was positively associated with AA therapeutic effect (104). Furthermore, the change of CTC counts was used as an endpoint in patients with mCRPC to determine the efficacy and tolerability of cabozantinib at lower starting doses $(36,105)$. For the first time, Dorff et al (25) detected CTCs in men with biochemical recurrence $\mathrm{PCa}$ to monitor the therapeutic effect of a combination herbal supplement, Prostate Health Cocktail.

In addition, molecular profile may be characterized in CTC as a potential predictive value of tumor sensitivity to a therapeutic modality or not (Table III), potential clinical uses of CTCs in determining prognosis and monitoring treatment effects, and as a source of tissue to identify predictive markers of drug sensitivity to guide treatment selection. Data from quantitative RT-PCR to detect circulating prostate-derived PSA and PSMA mRNA pre- and post- radical prostatectomy improves the accuracy of the Kattan nomogram to predict biochemical recurrence (72). In addition, biomarker response to docetaxel treatment was detected in 20 patients with CRPC (75). In response to docetaxel treatment, KLK3 levels decreased in $80 \%$ (95\% CI, 60-100\%), PCA3 in 89\% (95\% CI, $68-100 \%)$ and TMPRSS2-ERG in $86 \%$ (95\% CI, 60-100\%) of patients. By contrast, the blood samples from all 32 healthy volunteers were reproducibly negative for all three markers. A longitudinal study of a single patient with PCa who received 
Table III. molecular profiling in prostate cancer circulating tumor cells as potential predictive value of tumor sensitivity to therapeutic modalities.

\begin{tabular}{llll}
\hline Therapeutic modalities & \multicolumn{1}{c}{ Molecular profiling } & \multicolumn{1}{c}{ Predictive value } \\
\hline Radical prostatectomy & PSA (-) & Biochemical recurrence (-) \\
& PSMA (-) & Biochemical recurrence (-) \\
Docetaxel & PCA3 (-) & Sensitivity \\
& TMPRSS2-ERG (-) & Sensitivity \\
& KLK3 (-) & Sensitivity \\
Abiraterone acetate & AR (+) & Resistance \\
& MYC (+) & Resistance \\
& Ki67 (+) & Resistance \\
& AR nuclear translocation $(+)$ & Resistance \\
Enzalutamide & AR-V7-positive & Resistance \\
Taxanes & AR-V7-positive & Resistance \\
Cabazitaxel & AR-V7-positive & Sensitivity \\
ADT & AR-V7-positive & Sensitivity \\
& Harboring AR mutation & Resistance & $(106)$ \\
& Wnt5a (+) & Resistance
\end{tabular}

(-), decreased; (+), increased; ADT, androgen deprivation therapy; PSA, prostate-specific antigen; PSMA, prostate-specific membrane antigen; PCA3, prostate cancer antigen 3; TMPRSS2-ERG, transmembrane protease serine 2 and ETS-related fusion gene; KLK, kallikrein-related peptidase; AR, androgen receptor; AR-V7, androgen receptor splice variant 7.

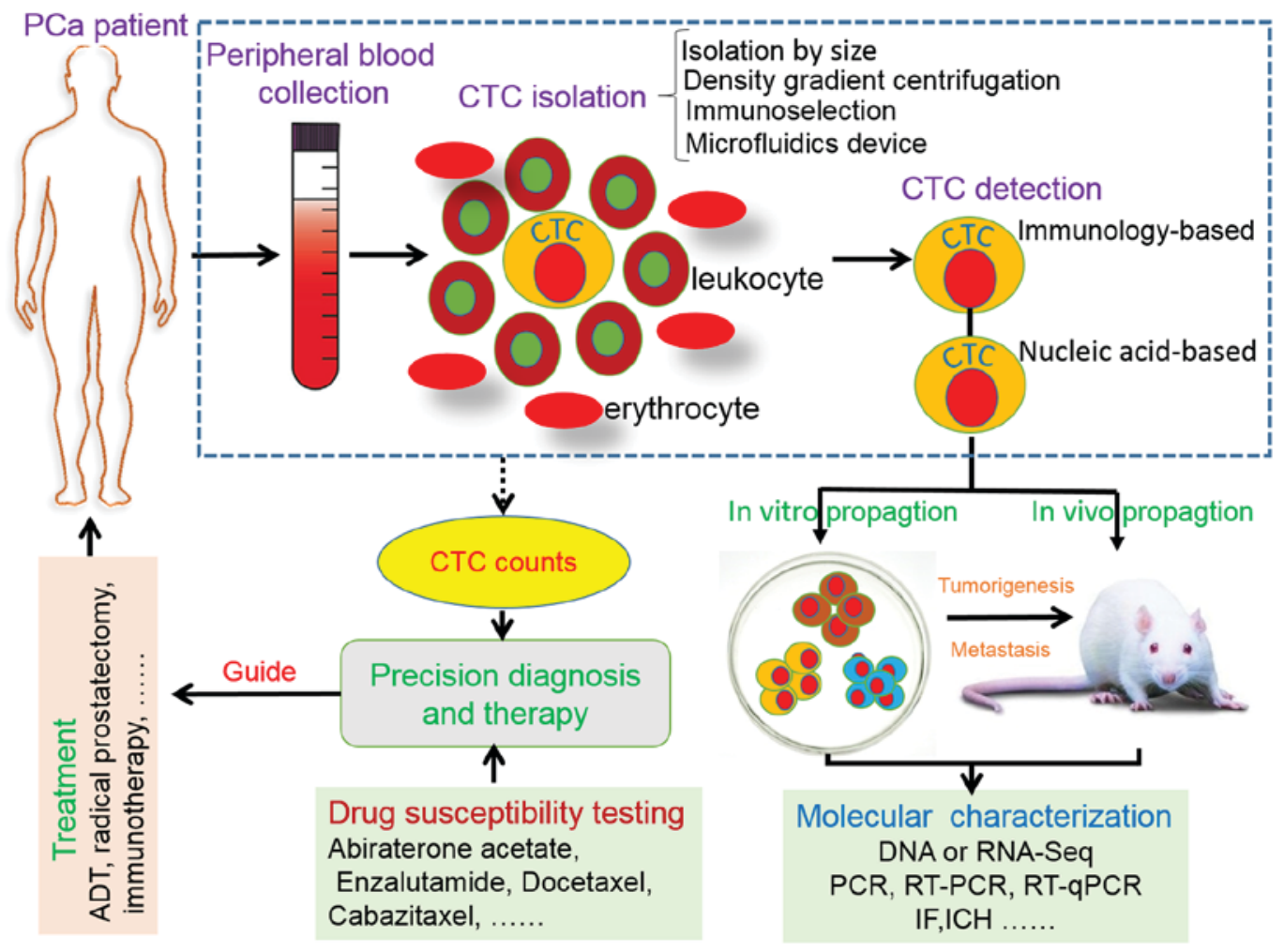

Figure 1. Circulating tumor cell in prostate cancer: Precision diagnosis and therapy.

AA treatment demonstrated that CTCs that acquired AR and MYC gene amplification represented a novel lineage, apparently resistant to AA, and possibly generated from a single resistant cell (106). In addition, despite intrapatient heterogeneity, CTCs from patients with prior exposure to abiraterone had increased the proliferation marker Ki67 expression, and qualitatively, the majority of AR staining within CTCs was intranuclear in subcellular localization (107).

Several studies have demonstrated that detection of AR-V7 in circulating tumor cells from patients with mCRPC 
may be associated with resistance to enzalutamide and abiraterone $(76,108)$. However, in AR-V7-positive men, taxanes appear to be more efficacious than enzalutamide or abiraterone therapy, whereas in AR-V7-negative men, taxanes and enzalutamide or abiraterone may have comparable efficacy (108). In addition, Onstenk et al (109) recently demonstrated that the response to cabazitaxel appeared to be independent of the AR-V7 status of CTCs from patients with mCRPC. Consequently, cabazitaxel may be a valid treatment option for patients with AR-V7-positive CTCs. In addition, patients with PCa harbored AR point mutations (a p.T878A point mutation and a p.H875Y mutation), which was another common AR modification mediating resistance to androgen deprivation therapy (34).

Furthermore, CTCs may be used as a viable pharmacodynamic marker to provide additional information on the safety profile and efficacy of agents. A phase I study determined the maximum tolerated dose of AEZS-108 in men with taxane- and CRPC, which was partly based on AEZS-108 internalization in CTCs using its autofluorescence (35).

In conclusion, CTC detection and characterization have shown potential to monitor cancer treatment and guide precision cancer therapies; however, the molecular profile of CTCs requires additional study and exploration, and more rigorous large clinical trials are required to confirm its clinical utility.

\section{CTC culture}

Stable long-term in vitro and in vivo CTC cultures may provide an opportunity for high-throughput preclinical testing of therapeutic regimens; however, until recently this has had limited success (110). In 2014, Yu et al (30) reported a landmark study, in which they established CTC cultures from 6 patients with estrogen receptor-positive breast cancer. Of the 5 CTC lines tested, 3 were tumorigenic in mice. Drug sensitivity testing of CTC lines with multiple mutations revealed potential new therapeutic targets, which could aid the identification of the best therapies for individual cancer patients over the course of their disease. Bichsel et al (110) demonstrated the feasibility of merging CTC capture with three-dimensional tumor cell culture by extracting PC 3 cells with the microchip and culturing them on-chip for 6 days. Furthermore, CTCs isolated from patients with mPCa could survive and grow in xenotransplants to retain a long-survive capacity (26). Gao et al (111) successfully established a prostate CTC line from $>100$ CTCs, followed by culture in vitro for $>9$ months using organoid conditions modified to support the growth of prostate tumor cells. In summary, with the ceaseless optimization and development of CTC culture techniques, prediction of treatment responses and disease progression should ultimately be improved.

\section{Conclusion}

The present study mainly described current advances in CTC enrichment and detection strategies, and reviewed how CTCs could move toward precision diagnosis and therapy in PCa (Fig. 1). Recently, Miyamoto et al reported a landmark study on RNA-sequencing (RNA-Seq) of single prostate
CTCs (112). This study established single-cell RNA-Seq profiles of 77 intact CTCs isolated from 13 patients (mean, 6 CTCs per patient), by using microfluidic enrichment. It was found that single-cell analysis of prostate CTCs revealed heterogeneity in signaling pathways, most importantly, ectopic expression of Wnt5a in PCa cells could attenuate the antiproliferative effect of AR inhibition, whereas its suppression in drug-resistant cells restored partial sensitivity (112). Beyond that, circulating tumor cells may be used as potential therapeutic targets for PCa treatment; killing and eliminating circulating tumor cells has become a novel and effective strategy for PCa therapy $(113,114)$, and surrogate predictors of survival could shorten drug trials for PCa treatment (115). In conclusion, there is great promise in utilizing CTCs as a platform for precision diagnosis and therapy in PCa. Although the future is bright, there is also a huge challenge. More sensitive and effective devices for CTC enrichment and detection are urgently required to be developed. More importantly, CTC assays require validation in clinical trials to achieve clinical validity and clinical utility.

\section{References}

1. Siegel RL, Miller KD and Jemal A: Cancer statistics, 2015. CA Cancer J Clin 65: 5-29, 2015.

2. Prostate cancer: Send away the PSA? Lancet 380: 307, 2012.

3. Marugame T and Katanoda K: International comparisons of cumulative risk of breast and prostate cancer, from cancer incidence in five continents Vol. VIII. Jpn J Clin Oncol 36: 399-400, 2006.

4. Lee J, Demissie K, Lu SE and Rhoads GG: Cancer incidence among Korean-American immigrants in the United States and native Koreans in South Korea. Cancer Control 14: 78-85, 2007.

5. Sottnik JL, Dai J, Zhang H, Campbell B and Keller ET: Tumorinduced pressure in the bone microenvironment causes osteocytes to promote the growth of prostate cancer bone metastases. Cancer Res 75: 2151-2158, 2015.

6. Fan L, Peng G, Sahgal N, Fazli L, Gleave M, Zhang Y, Hussain A and Qi J: Regulation of c-Myc expression by the histone demethylase JMJD1A is essential for prostate cancer cell growth and survival. Oncogene 35: 2441-2452, 2016.

7. Lee S, Luong R, Johnson DT, Cunha GR, Rivina L, Gonzalgo ML and Sun Z: Androgen signaling is a confounding factor for $\beta$-catenin-mediated prostate tumorigenesis. Oncogene 35: 702-714, 2016.

8. de Bono JS, Oudard S, Ozguroglu M, Hansen S, Machiels JP, Kocak I, Gravis G, Bodrogi I, Mackenzie MJ, Shen L, et al: Prednisone plus cabazitaxel or mitoxantrone for metastatic castration-resistant prostate cancer progressing after docetaxel treatment: A randomised open-label trial. Lancet 376: 1147-1154, 2010.

9. Fizazi K, Carducci M, Smith M, Damião R, Brown J, Karsh L, Milecki P, Shore N, Rader M, Wang H, et al: Denosumab versus zoledronic acid for treatment of bone metastases in men with castration-resistant prostate cancer: A randomised, double-blind study. Lancet 377: 813-822, 2011.

10. Laderach DJ, Gentilini LD, Giribaldi L, Delgado VC, Nugnes L, Croci DO, Al Nakouzi N, Sacca P, Casas G, Mazza O, et al: A unique galectin signature in human prostate cancer progression suggests galectin-1 as a key target for treatment of advanced disease. Cancer Res 73: 86-96, 2013.

11. Trewartha D and Carter K: Advances in prostate cancer treatment. Nat Rev Drug Discov 12: 823-824, 2013.

12. Violette PD, Agoritsas T, Alexander P, Riikonen J, Santti H, Agarwal A, Bhatnagar N, Dahm P, Montori V, Guyatt GH and Tikkinen KA: Decision aids for localized prostate cancer treatment choice: Systematic review and meta-analysis. CA Cancer J Clin 65: 239-251, 2015.

13. Locke JA, Guns ES, Lubik AA, Adomat HH, Hendy SC, Wood CA, Ettinger SL, Gleave ME and Nelson CC: Androgen levels increase by intratumoral de novo steroidogenesis during progression of castration-resistant prostate cancer. Cancer Res 68: 6407-6415, 2008. 
14. Gundem G, Van Loo P, Kremeyer B, Alexandrov LB, Tubio JM, Papaemmanuil E, Brewer DS, Kallio HM, Högnäs G, Annala M, et al: The evolutionary history of lethal metastatic prostate cancer. Nature 520: 353-357, 2015.

15. Lee KC, Sud S, Meyer CR, Moffat BA, Chenevert TL, Rehemtulla A, Pienta KJ and Ross BD: An imaging biomarker of early treatment response in prostate cancer that has metastasized to the bone. Cancer Res 67: 3524-3528, 2007.

16. Stephan C, Cammann H, Meyer HA, Lein M and Jung K: PSA and new biomarkers within multivariate models to improve early detection of prostate cancer. Cancer Lett 249: 18-29, 2007.

17. Barbieri CE, Baca SC, Lawrence MS, Demichelis F, Blattner M, Theurillat JP, White TA, Stojanov P, Van Allen E, Stransky N, et al: Exome sequencing identifies recurrent SPOP, FOXA1 and MED12 mutations in prostate cancer. Nat Genet 44: 685-689. 2012.

18. Cristofanilli M, Budd GT, Ellis MJ, Stopeck A, Matera J, Miller MC, Reuben JM, Doyle GV, Allard WJ, Terstappen LW and Hayes DF: Circulating tumor cells, disease progression and survival in metastatic breast cancer. N Engl J Med 351: 781-791, 2004.

19. de Bono JS, Scher HI, Montgomery RB, Parker C, Miller MC, Tissing H, Doyle GV, Terstappen LW, Pienta KJ and Raghavan D: Circulating tumor cells predict survival benefit from treatment in metastatic castration-resistant prostate cancer. Clin Cancer Res 14: 6302-6309, 2008.

20. Scher HI, Jia X, de Bono JS, Fleisher M, Pienta KJ, Raghavan D and Heller G: Circulating tumour cells as prognostic markers in progressive, castration-resistant prostate cancer: a reanalysis of IMMC38 trial data. Lancet Oncol 10: 233-239, 2009.

21. Olmos D, Arkenau HT, Ang JE, Ledaki I, Attard G, Carden CP, Reid AH, A'Hern R, Fong PC, Oomen NB, et al: Circulating tumour cell (CTC) counts as intermediate end points in castrationresistant prostate cancer (CRPC): A single-centre experience. Ann Oncol 20: 27-33, 2009.

22. Danila DC, Heller G, Gignac GA, Gonzalez-Espinoza R, Anand A, Tanaka E, Lilja H, Schwartz L, Larson S, Fleisher M and Scher HI: Circulating tumor cell number and prognosis in progressive castration-resistant prostate cancer. Clin Cancer Res 13: 7053-7058, 2007

23. Nagrath S, Sequist LV, Maheswaran S,Bell DW, Irimia D,Ulkus L, Smith MR, Kwak EL, Digumarthy S, Muzikansky A, et al Isolation of rare circulating tumour cells in cancer patients by microchip technology. Nature 450: 1235-1239, 2007.

24. Chen JF, Ho H, Lichterman J, Lu YT, Zhang Y, Garcia MA, Chen SF, Liang AJ, Hodara E, Zhau HE, et al: Subclassification of prostate cancer circulating tumor cells by nuclear size reveals very small nuclear circulating tumor cells in patients with visceral metastases. Cancer 121: 3240-3251, 2015.

25. Dorff TB, Groshen S, Tsao-Wei DD, Xiong S, Gross ME, Vogelzang N, Quinn DI and Pinski JK: A Phase II trial of a combination herbal supplement for men with biochemically recurrent prostate cancer. Prostate Cancer Prostatic Dis 17: 359-365, 2014

26. Rossi E, Rugge M, Facchinetti A, Pizzi M, Nardo G, Barbieri V, Manicone M, De Faveri S, Chiara Scaini M, Basso U, et al: Retaining the long-survive capacity of circulating tumor cells (CTCs) followed by xeno-transplantation: Not only from metastatic cancer of the breast but also of prostate cancer patients. Oncoscience 1: 49-56, 2013.

27. Paris PL, Kobayashi Y, Zhao Q, Zeng W, Sridharan S, Fan T, Adler HL, Yera ER, Zarrabi MH, Zucker S, et al: Functional phenotyping and genotyping of circulating tumor cells from patients with castration resistant prostate cancer. Cancer Lett 277: 164-173, 2009.

28. Helzer KT, Barnes HE, Day L, Harvey J, Billings PR and Forsyth A: Circulating tumor cells are transcriptionally similar to the primary tumor in a murine prostate model. Cancer Res 69 : 7860-7866, 2009.

29. Lohr JG, Adalsteinsson VA, Cibulskis K, Choudhury AD, Rosenberg M, Cruz-Gordillo P, Francis JM, Zhang CZ, Shalek AK, Satija R, et al: Whole-exome sequencing of circulating tumor cells provides a window into metastatic prostate cancer. Nat Biotechnol 32: 479-484, 2014.

30. Yu M, Bardia A, Aceto N, Bersani F, Madden MW, Donaldson MC, Desai R, Zhu H, Comaills V, Zheng Z, et al: Cancer therapy. Ex vivo culture of circulating breast tumor cells for individualized testing of drug susceptibility. Science 345: 216-220, 2014
31. Ni X, Zhuo M, Su Z, Duan J, Gao Y, Wang Z, Zong C, Bai H, Chapman AR, Zhao J, et al: Reproducible copy number variation patterns among single circulating tumor cells of lung cancer patients. Proc Natl Acad Sci USA 110: 21083-21088, 2013

32. Steinert G, Schölch S, Niemietz T, Iwata N, García SA, Behrens B Voigt A, Kloor M, Benner A, Bork U, et al: Immune escape and survival mechanisms in circulating tumor cells of colorectal cancer. Cancer Res 74: 1694-1704, 2014.

33. Anantharaman A and Friedlander TW: A stepping stone toward personalized oncology: Genomic analysis of circulating tumor cells to guide management of metastatic castration-resistant prostate cancer. Eur Urol 68: 946-948, 2015.

34. Steinestel J, Luedeke M, Arndt A, Schnoeller TJ, Lennerz JK, Wurm C, Maier C, Cronauer MV, Steinestel K and Schrader AJ: Detecting predictive androgen receptor modifications in circulating prostate cancer cells. Oncotarget: Apr 23, 2015 (Epub ahead of print).

35. Liu SV, Tsao-Wei DD, Xiong S, Groshen S, Dorff TB, Quinn DI, Tai YC, Engel J, Hawes D, Schally AV and Pinski JK: Phase I, dose-escalation study of the targeted cytotoxic LHRH analog AEZS-108 in patients with castration- and taxane-resistant prostate cancer. Clin Cancer Res 20: 6277-6283, 2014.

36. Lee RJ, Saylor PJ, Michaelson MD, Rothenberg SM, Smas ME, Miyamoto DT, Gurski CA, Xie W, Maheswaran S, Haber DA, et al: A dose-ranging study of cabozantinib in men with castration-resistant prostate cancer and bone metastases. Clin Cancer Res 19: 3088-3094, 2013.

37. Coumans FA, van Dalum G, Beck M and Terstappen LW: Filter characteristics influencing circulating tumor cell enrichment from whole blood. PLoS One 8: e61770, 2013.

38. Allard WJ, Matera J, Miller MC, Repollet M, Connelly MC, Rao C, Tibbe AG, Uhr JW and Terstappen LW: Tumor cells circulate in the peripheral blood of all major carcinomas but not in healthy subjects or patients with nonmalignant diseases. Clin Cancer Res 10: 6897-6904, 2004

39. Gleghorn JP, Pratt ED, Denning D, Liu H, Bander NH, Tagawa ST, Nanus DM, Giannakakou PA and Kirby BJ: Capture of circulating tumor cells from whole blood of prostate cancer patients using geometrically enhanced differential immunocapture (GEDI) and a prostate-specific antibody. Lab Chip 10: 27-29, 2010.

40. Xu L, Mao X, Imrali A, Syed F, Mutsvangwa K, Berney D, Cathcart P, Hines J, Shamash J and Lu YJ: Optimization and evaluation of a novel size based circulating tumor cell isolation system. PLoS One 10: e0138032, 2015.

41. Joshi P, Jacobs B, Derakhshan A, Moore LR, Elson P, Triozzi PL, Borden $\mathrm{E}$ and Zborowski M: Enrichment of circulating melanoma cells (CMCs) using negative selection from patients with metastatic melanoma. Oncotarget 5: 2450-2461, 2014.

42. Toss A, Mu Z, Fernandez S and Cristofanilli M: CTC enumeration and characterization: Moving toward personalized medicine. Ann Transl Med 2: 108-108, 2014.

43. Qin X, Park S, Duffy SP, Matthews K, Ang RR, Todenhöfer T, Abdi H, Azad A, Bazov J, Chi KN, et al: Size and deformability based separation of circulating tumor cells from castrate resistant prostate cancer patients using resettable cell traps. Lab Chip 15: 2278-2286, 2015 .

44. Sunyoung P, Ang RR, Duffy SP, Bazov J, Chi KN, Black PC and Ma H: Morphological differences between circulating tumor cells from prostate cancer patients and cultured prostate cancer cells. PLoS One 9: e85264, 2014.

45. Rosenberg R, Gertler R, Friederichs J, Fuehrer K, Dahm M, Phelps R, Thorban S, Nekarda H and Siewert JR: Comparison of two density gradient centrifugation systems for the enrichment of disseminated tumor cells in blood. Cytometry 49: 150-158, 2002.

46. Woelfle U, Breit E, Zafrakas K, Otte M, Schubert F, Müller V, Izbicki JR, Löning T and Pantel K: Bi-specific immunomagnetic enrichment of micrometastatic tumour cell clusters from bone marrow of cancer patients. J Immunol Methods 300: 136-145, 2005.

47. Coumans FA, Doggen CJ, Attard G, de Bono JS and Terstappen LW: All circulating EpCAM+CK+CD45-objects predict overall survival in castration-resistant prostate cancer. Ann Oncol 21: 1851-1857, 2010.

48. Riethdorf S, Fritsche H, Müller V, Rau T, Schindlbeck C, Rack B, Janni W, Coith C, Beck K, Jänicke F, et al: Detection of circulating tumor cells in peripheral blood of patients with metastatic breast cancer: A validation study of the CellSearch system. Clin Cancer Res 13: 920-928, 2007. 
49. Dotan E, Cohen SJ, Alpaugh KR and Meropol NJ: Circulating tumor cells: Evolving evidence and future challenges. Oncologist 14: 1070-1082, 2009.

50. Pavese JM and Bergan RC: Circulating tumor cells exhibit a biologically aggressive cancer phenotype accompanied by selective resistance to chemotherapy. Cancer Lett 352: 179-186, 2014.

51. Bitting RL, Boominathan R, Rao C, Kemeny G, Foulk B, GarciaBlanco MA, Connelly M and Armstrong AJ: Development of a method to isolate circulating tumor cells using mesenchymal-based capture. Methods 64: 129-136, 2013.

52. Santana SM, Liu H, Bander NH, Gleghorn JP and Kirby BJ: Immunocapture of prostate cancer cells by use of anti-PSMA antibodies in microdevices. Biomed Microdevices 14: 401-407, 2012.

53. Witzig TE, Bossy B, Kimlinger T, Roche PC, Ingle JN, Grant C, Donohue J, Suman VJ, Harrington D, Torre-Bueno J and Bauer KD: Detection of circulating cytokeratin-positive cells in the blood of breast cancer patients using immunomagnetic enrichment and digital microscopy. Clin Cancer Res 8 : 1085-1091, 2002

54. Lu YT, Zhao L, Shen Q, Garcia MA, Wu D, Hou S, Song M, Xu X, Ouyang WH, Ouyang WW, et al: NanoVelcro Chip for CTC enumeration in prostate cancer patients. Methods 64 $144-152,2013$

55. Viraka Nellore BP, Kanchanapally R, Pramanik A, Sinha SS Chavva SR, Hamme A II and Ray PC: Aptamer-conjugated graphene oxide membranes for highly efficient capture and accurate identification of multiple types of circulating tumor cells Bioconjug Chem 26: 235-242, 2015.

56. Antfolk M, Magnusson C, Augustsson P, Lilja H and Laurell T: Acoustofluidic, label-free separation and simultaneous concentration of rare tumor cells from white blood cells. Anal Chem 87: 9322-9328, 2015

57. Huang SB, Wu MH, Lin YH, Hsieh CH, Yang CL, Lin HC Tseng CP and Lee GB: High-purity and label-free isolation of circulating tumor cells (CTCs) in a microfluidic platform by using optically-induced-dielectrophoretic (ODEP) force. Lab on A Chip 13: 1371-1383, 2013.

58. Ozkumur E, Shah AM, Ciciliano JC, Emmink BL, Miyamoto DT Brachtel E, Yu M, Chen PI, Morgan B, Trautwein J, et al: Inertial focusing for tumor antigen-dependent and -independent sorting of rare circulating tumor cells. Sci Transl Med 5: 179ra47, 2013.

59. Autebert J, Coudert B, Champ J, Saias L, Guneri ET, Lebofsky R, Bidard FC, Pierga JY, Farace F, Descroix S, et al: High purity microfluidic sorting and analysis of circulating tumor cells: Towards routine mutation detection. Lab Chip 15: 2090-2101, 2015.

60. Antfolk M, Antfolk C, Lilja H, Laurell T and Augustsson P: A single inlet two-stage acoustophoresis chip enabling tumor cel enrichment from white blood cells. Lab Chip 15: 2102-2109, 2015.

61. Sarioglu AF, Aceto N, Kojic N, Donaldson MC, Zeinali M, Hamza B, Engstrom A, Zhu H, Sundaresan TK, Miyamoto DT, et al: A microfluidic device for label-free, physical capture of circulating tumor cell clusters. Nat Methods 12: 685-691, 2015.

62. Hou JM, Krebs M, Ward T, Morris K, Sloane R, Blackhall F and Dive C: Circulating tumor cells, enumeration and beyond. Cancers (Basel) 2: 1236-1250, 2010.

63. Stott SL, Lee RJ, Nagrath S, Yu M, Miyamoto DT, Ulkus L, Inserra EJ, Ulman M, Springer S, Nakamura Z, et al: Isolation and characterization of circulating tumor cells from patients with localized and metastatic prostate cancer. Sci Transl Med 2: 25ra23, 2010

64. Kirby BJ, Jodari M, Loftus MS, Gakhar G, Pratt ED, Chanel-Vos C, Gleghorn JP, Santana SM, Liu H, Smith JP, et al: Functional characterization of circulating tumor cells with a prostate-cancer-specific microfluidic device. PLoS One 7: e35976, 2012.

65. Friedlander TW, Ngo VT, Dong H, Premasekharan G, Weinberg V, Doty S, Zhao Q, Gilbert EG, Ryan CJ, Chen WT and Paris PL: Detection and characterization of invasive circulating tumor cells derived from men with metastatic castration-resistant prostate cancer. Int J Cancer 134: 2284-2293, 2014.

66. Tseng JY, Yang CY, Liang SC, Liu RS, Jiang JK and Lin CH: Dynamic changes in numbers and properties of circulating tumor cells and their potential applications. Cancers (Basel) 6 : $2369-2386,2014$

67. Myung JH, Gajjar KA, Chen J, Molokie RE and Hong S: Differential detection of tumor cells using a combination of cell rolling, multivalent binding, and multiple antibodies. Anal Chem 86: 6088-6094, 2014.
68. Gerges N, Rak J and Jabado N: New technologies for the detection of circulating tumour cells. Br Med Bull 94: 49-64, 2010

69. Helo P, Cronin AM, Danila DC, Wenske S, Gonzalez-Espinoza R, Anand A, Koscuiszka M, Väänänen RM, Pettersson K, Chun FK, et al: Circulating prostate tumor cells detected by reverse transcription-PCR in men with localized or castration-refractory prostate cancer: Concordance with CellSearch assay and association with bone metastases and with survival. Clin Chem 55 765-773, 2009.

70. Gervasoni A, Monasterio Muñoz RM, Wengler GS, Rizzi A, Zaniboni A and Parolini O: Molecular signature detection of circulating tumor cells using a panel of selected genes. Cancer Lett 263: 267-279, 2008.

71. Stott SL, Hsu CH, Tsukrov DI, Yu M, Miyamoto DT, Waltman BA, Rothenberg SM, Shah AM, Smas ME, Korir GK, et al: Isolation of circulating tumor cells using a microvortex-generating herringbone-chip. Proc Natl Acad Sci USA 107: 18392-18397, 2010.

72. Yates DR, Rouprêt M, Drouin SJ, Comperat E, Ricci S, Lacave R, Sèbe P, Cancel-Tassin G, Bitker MO and Cussenot O: Quantitative RT-PCR analysis of PSA and prostate-specific membrane antigen mRNA to detect circulating tumor cells improves recurrence-free survival nomogram prediction after radical prostatectomy. Prostate 72: 1382-1388, 2012.

73. Mohamadi RM, Ivanov I, Stojcic J, Nam RK, Sargent EH and Kelley SO: Sample-to-answer isolation and mRNA profiling of circulating tumor cells. Anal Chem 87: 6258-6264, 2015.

74. Jiang Y, Palma JF, Agus DB, Wang Y and Gross ME: Detection of androgen receptor mutations in circulating tumor cells in castration-resistant prostate cancer. Clin Chem 56: 1492-1495, 2010.

75. Dijkstra S, Leyten GH, Jannink SA, de Jong H, Mulders PF, van Oort IM and Schalken JA: KLK3,PCA3 and TMPRSS2-ERG expression in the peripheral blood mononuclear cell fraction from castration-resistant prostate cancer patients and response to docetaxel treatment. Prostate 74: 1222-1230, 2014.

76. Antonarakis ES, Lu C, Wang H, Luber B, Nakazawa M, Roeser JC, Chen Y, Mohammad TA, Chen Y, Fedor HL, et al: AR-V7 and resistance to enzalutamide and abiraterone in prostate cancer. N Engl J Med 371: 1028-1038, 2014.

77. Panteleakou Z, Lembessis P, Sourla A, Pissimissis N, Polyzos A, Deliveliotis $C$ and Koutsilieris M: Detection of circulating tumor cells in prostate cancer patients: Methodological pitfalls and clinical relevance. Mol Med 15: 101-114, 2009.

78. Sioss JA, Bhiladvala RB, Pan W, Li M, Patrick S, Xin P, Dean SL, Keating CD, Mayer TS and Clawson GA: Nanoresonator chip-based RNA sensor strategy for detection of circulating tumor cells: Response using PCA3 as a prostate cancer marker. Nanomedicine 8: 1017-1025, 2012.

79. Ivanov I, Stojcic J, Stanimirovic A, Sargent E, Nam RK and Kelley SO: Chip-based nanostructured sensors enable accurate identification and classification of circulating tumor cells in prostate cancer patient blood samples. Anal Chem 85: 398-403, 2013

80. Gu Y, Ju C, Li Y, Shang Z, Wu Y, Jia Y and Niu Y: Detection of circulating tumor cells in prostate cancer based on carboxylated graphene oxide modified light addressable potentiometric sensor. Biosens Bioelectron 66: 24-31, 2015.

81. Kerr BA, Miocinovic R, Smith AK, West XZ, Watts KE, Alzayed AW, Klink JC, Mir MC, Sturey T, Hansel DE, et al: $\mathrm{CD} 117^{+}$cells in the circulation are predictive of advanced prostate cancer. Oncotarget 6: 1889-1897, 2015.

82. Wang H, Yang M, Xu J, Zou B, Zhou Q, Bian J and Wang X: Survivin mRNA-circulating tumor cells are associated with prostate cancer metastasis. Tumour Biol 37: 723-727, 2016.

83. Danila DC, Anand A, Schultz N, Heller G, Wan M, Sung CC, Dai C, Khanin R, Fleisher M, Lilja H and Scher HI: Analytic and clinical validation of a prostate cancer-enhanced messenger RNA detection assay in whole blood as a prognostic biomarker for survival. Eur Urol 65: 1191-1197, 2014.

84. Moreno JG, Miller MC, Gross S, Allard WJ, Gomella LG and Terstappen LW: Circulating tumor cells predict survival in patients with metastatic prostate cancer. Urology 65: 713-718, 2005.

85. Scher HI, Jia X, de Bono JS, Fleisher M, Pienta KJ, Raghavan D and Heller G: Circulating tumour cells as prognostic markers in progressive, castration-resistant prostate cancer: A reanalysis of IMMC38 trial data. Lancet Oncol 10: 233-239, 2009.

86. Thalgott $M$, Heck MM, Eiber M, Souvatzoglou $M$, Hatzichristodoulou G, Kehl V, Krause BJ, Rack B, Retz M, Gschwend JE, et al: Circulating tumor cells versus objective response assessment predicting survival in metastatic castration-resistant prostate cancer patients treated with docetaxel chemotherapy. J Cancer Res Clin Oncol 141: 1457-1464, 2015. 
87. Marín-Aguilera M, Reig Ò, Lozano JJ, Jiménez N, García-Recio S, Erill N, Gaba L, Tagliapietra A, Ortega V, Carrera G, et al: Molecular profiling of peripheral blood is associated with circulating tumor cells content and poor survival in metastatic castration-resistant prostate cancer. Oncotarget 6: 10604-10616, 2015.

88. Goldkorn A, Ely B, Tangen CM, Tai YC, Xu T, Li H, Twardowski P, Veldhuizen PJ, Agarwal N, Carducci MA, et al: Circulating tumor cell telomerase activity as a prognostic marker for overall survival in SWOG 0421: A phase III metastatic castration resistant prostate cancer trial. Int J Cancer 136: 1856-1862, 2015.

89. Thalgott M, Rack B, Maurer T, Souvatzoglou M, Eiber M, Kreß V, Heck MM, Andergassen U, Nawroth R, Gschwend JE and Retz M: Detection of circulating tumor cells in different stages of prostate cancer. J Cancer Res Clin Oncol 139: 755-763, 2013.

90.Loh J, Jovanovic L, Lehman M, Capp A, Pryor D, Harris M, Nelson C and Martin J: Circulating tumor cell detection in high-risk non-metastatic prostate cancer. J Cancer Res Clin Oncol 140: 2157-2162, 2014

91. Davis JW, Nakanishi H, Kumar VS, Bhadkamkar VA, McCormack R, Fritsche HA, Handy B, Gornet T and Babaian RJ: Circulating tumor cells in peripheral blood samples from patients with increased serum prostate specific antigen: Initial results in early prostate cancer. J Urol 179: 2187-2191, 2008.

92. Kolostova K, Broul M, Schraml J, Cegan M, Matkowski R, Fiutowski $\mathrm{M}$ and Bobek V: Circulating tumor cells in localized prostate cancer: Isolation, cultivation in vitro and relationship to T-stage and Gleason score. Anticancer Res 34: 3641-3646, 2014

93. Bitting RL, Healy P, Halabi S, George DJ, Goodin M and Armstrong AJ: Clinical phenotypes associated with circulating tumor cell enumeration in metastatic castration-resistant prostate cancer. Urol Oncol 33: 110.e1-9, 2015.

94. Schoenborn JR, Nelson P and Fang M: Genomic profiling defines subtypes of prostate cancer with the potential for therapeutic stratification. Clin Cancer Res 19: 4058-4066, 2013

95. Chen CL, Mahalingam D, Osmulski P, Jadhav RR, Wang CM, Leach RJ, Chang TC, Weitman SD, Kumar AP, Sun L, et al: Single-cell analysis of circulating tumor cells identifies cumulative expression patterns of EMT-related genes in metastatic prostate cancer. Prostate 73: 813-826, 2013.

96. Osmulski P, Mahalingam D, Gaczynska ME, Liu J, Huang S, Horning AM, Wang CM, Thompson IM, Huang TH and Chen CL: Nanomechanical biomarkers of single circulating tumor cells for detection of castration resistant prostate cancer. Prostate 74: 1297-1307, 2014.

97. Boegemann M, Schrader AJ, Krabbe LM and Herrmann E: Present, emerging and possible future biomarkers in castration resistant prostate cancer (CRPC). Curr Cancer Drug Targets 15: 243-255, 2015.

98. Alexandrov LB, Nik-Zainal S, Wedge DC, Aparicio SA, Behjati S, Biankin AV, Bignell GR, Bolli N, Borg A, Børresen-Dale AL, et al: Signatures of mutational processes in human cancer. Nature 500: 415-421, 2013.

99. Stratton MR: Exploring the genomes of cancer cells: Progress and promise. Science 331: 1553-1558, 2011.

100. Pantel K, Brakenhoff RH and Brandt B: Detection, clinical relevance and specific biological properties of disseminating tumour cells. Nat Rev Cancer 8: 329-340, 2008.

101. Alix-Panabières C, Schwarzenbach $\mathrm{H}$ and Pantel K: Circulating tumor cells and circulating tumor DNA. Annu Rev Med 63: $199-215,2011$.
102. Wang J, McGuire TR, Britton HC, Schwarz JK, Loberiza FR Jr, Meza JL and Talmadge JE: Lenalidomide and cyclophosphamide immunoregulation in patients with metastatic, castration-resistant prostate cancer. Clin Exp Metastasis 32: 111-124, 2015.

103. Wilbaux M, Tod M, De Bono J, Lorente D, Mateo J, Freyer G, You B and Hénin E: A joint model for the kinetics of CTC count and PSA concentration during treatment in metastatic castration-resistant prostate cancer. CPT Pharmacometrics Syst Pharmacol 4: 277-285, 2015.

104. Danila DC, Anand A, Sung CC, Heller G, Leversha MA, Cao L, Lilja H, Molina A, Sawyers CL, Fleisher M and Scher HI: TMPRSS2-ERG status in circulating tumor cells as a predictive biomarker of sensitivity in castration-resistant prostate cancer patients treated with abiraterone acetate. Eur Urol 60: 897-904, 2011.

105. Smith MR, Sweeney CJ, Corn PG, Rathkopf DE, Smith DC, Hussain M, George DJ, Higano CS, Harzstark AL, Sartor AO, et al: Cabozantinib in chemotherapy-pretreated metastatic castration-resistant prostate cancer: Results of a phase II nonrandomized expansion study. J Clin Oncol 32: 3391-3399, 2014.

106. Dago AE, Stepansky A, Carlsson A, Luttgen M, Kendall J, Baslan T, Kolatkar A, Wigler M, Bethel K, Gross ME, et al: Rapid phenotypic and genomic change in response to therapeutic pressure in prostate cancer inferred by high content analysis of single circulating tumor cells. PLoS One 9: e101777, 2014

107. Reyes EE, VanderWeele DJ, Isikbay M, Duggan R, Campanile A, Stadler WM, Vander Griend DJ and Szmulewitz RZ: Quantitative characterization of androgen receptor protein expression and cellular localization in circulating tumor cells from patients with metastatic castration-resistant prostate cancer. J Trans Med 12: 313, 2014.

108. Antonarakis ES, Lu C, Luber B, Wang H, Chen Y, Nakazawa M, Nadal R, Paller CJ, Denmeade SR, Carducci MA, et al: Androgen receptor splice variant 7 and efficacy of taxane chemotherapy in patients with metastatic castration-resistant prostate cancer. JAMA Oncol 1: 582-591, 2015.

109. Onstenk W, Sieuwerts AM, Kraan J, Van M, Nieuweboer AJ, Mathijssen RH, Hamberg P, Meulenbeld HJ, De Laere B, Dirix LY, et al: Efficacy of cabazitaxel in castration-resistant prostate cancer is independent of the presence of AR-V7 in circulating tumor cells. Eur Urol 68: 939-945, 2015.

110. Bichsel CA, Gobaa S, Kobel S, Secondini C, Thalmann GN, Cecchini MG and Lutolf MP: Diagnostic microchip to assay 3D colony-growth potential of captured circulating tumor cells. Lab Chip 12: 2313-2316, 2012.

111. Gao D, Vela I, Sboner A, Iaquinta PJ, Karthaus WR, Gopalan A, Dowling C, Wanjala JN, Undvall EA, Arora VK, et al: Organoid cultures derived from patients with advanced prostate cancer. Cell 159: 176-187, 2014.

112. MiyamotoDT,Zheng Y,Wittner BS,LeeRJ,Zhu H,Broderick KT, Desai R, Fox DB, Brannigan BW, Trautwein J, et al: RNA-Seq of single prostate CTCs implicates noncanonical Wnt signaling in antiandrogen resistance. Science 349: 1351-1356, 2015.

113. Mitchell MJ, Wayne E, Rana K, Schaffer CB and King MR: TRAIL-coated leukocytes that kill cancer cells in the circulation. Proc Natl Acad Sci USA 111: 930-935, 2014.

114. Kim G and Gaitas A: Extracorporeal photo-immunotherapy for circulating tumor cells. PLoS One 10: e0127219, 2015.

115. Prostate cancer: send away the PSA? Cancer Discov 5: 570-571, 2015. 